\title{
Investigation of Local Scour Hole Dimensions around Circular Bridge Piers under Steady State Conditions
}

\author{
Ömer Yavuz ESK'́1 \\ Ayşegül ÖZGENÇ AKSOY²
}

\begin{abstract}
The local scour around bridge piers is one of the main causes of bridge failures. In this study, scour hole dimensions around circular bridge piers were investigated under clear water scour conditions for various steady flow rates. The experiments were performed with four different bridge pier diameters and seven different flow rates by using uniform sediment with a median diameter of $1.63 \mathrm{~mm}$ and geometric standard deviation of 1.3. After each experiments the bathymetry of scour hole was determined. New empirical equations to estimate scour hole length, scour hole width and scour hole volume $(\forall)$ are proposed by using experimental findings and experimental data available in the literature. The experimental results were also compared with those calculated using several empirical equations given by previous studies. Since there is a lack of data about scour hole dimensions, the experimental findings presented in this study are useful for the researchers investigating the local scour process, and have contributed to the few experimental data in the literature.
\end{abstract}

Keywords: Clear water scour, bridge piers, scour hole dimensions.

\section{INTRODUCTION}

Local scour around bridge piers is the one of the main reasons of the bridge failures. There are many studies related to scour depth estimation $[1,2,3,4,5,6,7,8,9,10,11,12,13,14$, $15,16,17]$. But there is still a lack of studies related to scour hole dimension estimation.

Yanmaz and Altinbilek [4] performed sets of experiments by using single cylindrical and square bridge pier models under clear water conditions with uniform bed materials. They proposed two equations to estimate the scour depth and the volume of the scour hole around the cylindrical pier.

\section{Note:}

- This paper was received on March 16, 2020 and accepted for publication by the Editorial Board on November 10, 2020.

- Discussions on this paper will be accepted by May 31, 2020.

- https://doi.org/10.18400/tekderg.704352

1 Dokuz Eylul University, Civil Engineering Department, İzmir, Turkey - omer.yavuz.eski@hotmail.com https://orcid.org/0000-0002-4737-8241

2 Dokuz Eylul University, Civil Engineering Department, İzmir, Turkey - aysegul.ozgenc@deu.edu.tr https://orcid.org/0000-0001-8779-5499 
Khwairakpam et al. [18] investigated local scour around circular bridge piers experimentally. In their study, the experiments were conducted under clear water and steady state flow conditions. On the basis of the experimental results, they proposed empirical equations to estimate scour hole depth, scour hole length, scour hole width, scour hole area and scour hole volume.

Das et al. [19] performed experiments to investigate equilibrium scour hole geometry around a circular pier. They proposed some empirical equations to predict the scour hole depth, scour hole length, scour hole width, scour hole area, and scour hole volume.

D'alessandro [20] performed experiments under clear water and steady state flow conditions with uniform bed materials to investigate local scour around circular bridge piers. He analyzed the effect of blockage on scour hole geometry in their experiments.

Hodi [21] carried out experiments to investigate scour geometry of circular bridge piers influenced by flume width in the laboratory condition. The experiments were conducted by using uniform sediment size under steady flow and clear water conditions.

Khan et al. [22] investigated local scour around various sizes and shapes bridge piers experimentally. The experiments were performed under clear water and steady state flow conditions with uniform sediment.

In this study, the shape of the scour hole around circular bridge piers was investigated under different steady state flow rate conditions by using four different bridge pier diameters. The dimension of the scour hole was determined after each experiment and new empirical equations were proposed to estimate scour hole length, scour hole width and scour hole volume (V).

\section{THEORETICAL BACKGROUND}

It is known that the dimension of the scour hole (scour length and scour width) is a function of equilibrium scour depth $d_{s}[18,19]$. Thus the parameters effecting the scour hole around a bridge pier are; density of the water $(\rho)$, dynamic viscosity of the water $(\mu)$, density of the bed material $\left(\rho_{s}\right)$, median grain size of the bed material $\left(d_{50}\right)$, pier diameter $(D)$, approach flow depth (h), velocity of the water $(\mathrm{V})$, acceleration due to gravity $(\mathrm{g})$, equilibrium scour depth $\left(\mathrm{d}_{\mathrm{s}}\right)$, and pier shape. Thus the value of the scour length can be written as

$L_{s}=f_{1}\left(\rho, \mu, \rho_{s}, d_{50}, D, h, V, g, d_{s}\right)$

The independent parameters $\rho, \rho_{\mathrm{s}}$ and g can be combined as $\mathrm{g}^{\prime}$ where $g^{\prime}=\left[\left(\rho_{s}-\rho\right) / \rho\right] g$ [19] and under turbulent flow conditions the effect of $\mu$ can be neglected. In addition, Densimetric Froude particle number $\left(\mathrm{F}_{\mathrm{d}}\right)$ has an important role for the scour process [10] and it is defined as $F_{d}=V / \sqrt{\left(g^{\prime} d_{50}\right)}$. The non-dimensional parameters were obtained by means of Buckingham $\pi$ theorem as.

$\frac{L_{s}}{D}=f_{3}\left(\frac{d_{s}}{D}, F_{d}\right)$

Similarly scour hole width $\left(\mathrm{W}_{\mathrm{s}}\right)$ and scour hole volume $(\forall)$ can be expressed as, 
$\frac{W_{s}}{D}=f_{3}\left(\frac{d_{s}}{D}, F_{d}\right)$

$\frac{\Downarrow}{D}=f_{3}\left(\frac{d_{s}}{D}, F_{d}\right)$

Some of the relations predicting the scour hole dimension are as follows:

Yanmaz and Altinbilek [4] suggested the following equation to estimate the volume of the scour hole.

$\nvdash=\frac{\pi}{3 \tan \phi}\left(\frac{d_{S}^{3}}{\tan \phi}+\frac{3 d_{S}^{2} b}{2}\right)$

where $\phi$ is the angle of repose of sediment.

Khwairakpam et al. [18] proposed Eq. (6), Eq. (7) and Eq. (8) to predict length, width and volume of the scour hole, respectively.

$L_{s}=\left\{3.958\left(\frac{h}{D}\right)-2.371\right\} d_{s}+\left\{-2.649\left(\frac{h}{D}\right)+5.082\right\}$

$\mathrm{W}_{\mathrm{s}}=\left\{6.204\left(\frac{\mathrm{h}}{\mathrm{D}}\right)-5.412\right\} \mathrm{d}_{\mathrm{s}}+\left\{-4.435\left(\frac{\mathrm{h}}{\mathrm{D}}\right)+7.597\right\}$

$V_{S}=\left\{-1.520\left(\frac{h}{D}\right)+3.661\right\} e^{(1.568(h / D)-0.716) d_{S}}$

where the units of the $d_{s}, L_{s}, W_{s}$ are $c m$ and $V_{s}$ is $\mathrm{cm}^{3}$.

Das et al. [19] have given the following equations to estimate length, width and volume of the scour hole.

$$
\begin{aligned}
& \frac{\mathrm{L}_{\mathrm{s}}}{D}=5.065\left(\frac{\mathrm{d}_{\mathrm{s}}}{\mathrm{D}}\right) \\
& \frac{\mathrm{W}_{\mathrm{s}}}{D}=5.576\left(\frac{\mathrm{d}_{\mathrm{s}}}{\mathrm{D}}\right) \\
& \frac{\sharp_{\mathrm{s}}}{\sharp_{\mathrm{c}}}=0.161 e^{\left(2.461\left(\frac{d_{\mathrm{s}}}{D}\right)\right)}
\end{aligned}
$$

where $\forall_{c}$ is the characteristic volume of pier below the water level.

\section{EXPERIMENTAL SET-UP, MEASUREMENT DEVICES AND METHOD}

The scheme of the experimental set-up is given in Fig. 1. The flume is $18.6 \mathrm{~m}$ long, $0.80 \mathrm{~m}$ wide and $0.75 \mathrm{~m}$ high. The slope of the flume was fixed to 0.006 . The bed material was uniform granular sediment with median diameter $\mathrm{d}_{50}$ of $1.63 \mathrm{~mm}$, geometric standard deviation of 1.3 and angle of repose of sediment $\phi$ of $33^{\circ}$. Sediment layer thickness was 0.26 $\mathrm{m}$. The bridge piers were located at $11.5 \mathrm{~m}$ from the upstream end of the flume. Before each 
experiment, the flume bed was readjusted by using a system moving on the rails over the side walls along the flume. The flow rates and approach flow depths were measured by using electromagnetic flow meter and ultrasonic level sensors (ULS), respectively.

It is observed that the scour depths did not change after 320 minutes in the case of the largest flow rate and pier diameter. So the duration of the experiments was designated as $480 \mathrm{~min}$ which is sufficient to reach the equilibrium scour depth and scour hole dimension.

The scheme of the experimental setup is given in Figure 1.

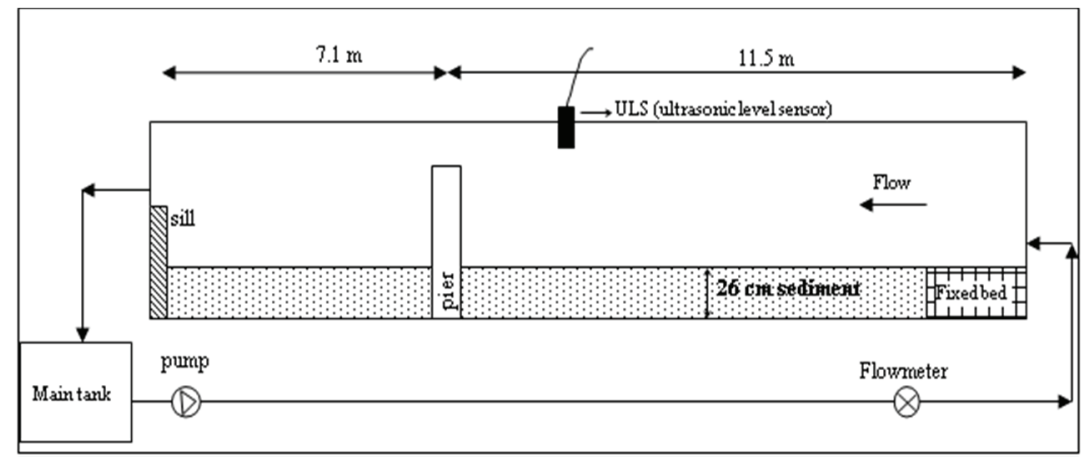

Fig. 1 - The scheme of the experimental set-up

\section{EXPERIMENTAL RESULTS}

28 experiments were performed by using seven different steady flow rates and four different circular bridge pier diameters.

The features of the experiments are given in Table 1 where $\mathrm{D}$ is pier diameter, $\mathrm{Q}$ is flow rate, $\mathrm{y}$ is approach flow depth, $\mathrm{F}_{\mathrm{d}}$ is densimetric Froude particle number and $\left(\mathrm{V} / \mathrm{V}_{\mathrm{c}}\right)$ is flow intensity.

The critical velocity $\mathrm{V}_{\mathrm{c}}$ is determined from the equation given below [23].

$\frac{V_{\mathrm{c}}}{u_{*_{c}}}=5.75 \log \left(5,53 \frac{y}{d_{50}}\right)$

where $u_{*_{c}}$ is the critical shear velocity which can be calculated by using the following relations [7]:

$u_{*_{c}}=0,0115+0,0125 d_{50}^{1,4} \quad$ for $0,1 \mathrm{~mm}<d_{50}<1 \mathrm{~mm}$

$u_{*_{c}}=0,0305 d_{50}{ }^{0,5}-0,0065 d_{50}{ }^{-1} \quad$ for $1 \mathrm{~mm}<d_{50}<100 \mathrm{~mm}$

In these relations $u_{*_{c}}$ is in $\mathrm{m} / \mathrm{s}$ and the sediment size $d_{50}$ is in $\mathrm{mm}$.

Clear water scour was observed since the flow intensity parameters $\left(\mathrm{V} / \mathrm{V}_{\mathrm{c}}\right)$ are smaller than 1 during the experiments. 
Table 1 - The features of the experiments

\begin{tabular}{|c|c|c|c|c|c|}
\hline $\begin{array}{c}\text { Experiment } \\
\text { No }\end{array}$ & $\begin{array}{c}\mathrm{D} \\
(\mathrm{cm})\end{array}$ & $\begin{array}{c}\mathrm{Q} \\
(\mathrm{l} / \mathrm{s})\end{array}$ & $\begin{array}{c}\mathrm{y} \\
(\mathrm{cm})\end{array}$ & $\mathrm{F}_{\mathrm{d}}$ & $\mathrm{V} / \mathrm{V}_{\mathrm{c}}$ \\
\hline AE1 & 8 & 43 & 19.5 & 1.70 & 0.49 \\
\hline AE2 & 8 & 47 & 20.2 & 1.79 & 0.51 \\
\hline AE3 & 8 & 53 & 20.7 & 1.97 & 0.56 \\
\hline AE4 & 8 & 57 & 21.3 & 2.06 & 0.58 \\
\hline AE5 & 8 & 62 & 22.3 & 2.14 & 0.60 \\
\hline AE6 & 8 & 66 & 22.7 & 2.24 & 0.63 \\
\hline AE7 & 8 & 71 & 23.4 & 2.33 & 0.65 \\
\hline AE8 & 11 & 43 & 19.5 & 1.70 & 0.49 \\
\hline AE9 & 11 & 47 & 20.2 & 1.79 & 0.51 \\
\hline AE10 & 11 & 53 & 20.7 & 1.97 & 0.56 \\
\hline AE11 & 11 & 57 & 21.3 & 2.06 & 0.58 \\
\hline AE12 & 11 & 62 & 22.3 & 2.14 & 0.60 \\
\hline AE13 & 11 & 66 & 22.7 & 2.24 & 0.63 \\
\hline AE14 & 11 & 71 & 23.4 & 2.33 & 0.65 \\
\hline AE15 & 15 & 43 & 19.5 & 1.70 & 0.49 \\
\hline AE16 & 15 & 47 & 20.2 & 1.79 & 0.51 \\
\hline AE17 & 15 & 53 & 20.7 & 1.97 & 0.56 \\
\hline AE18 & 15 & 57 & 21.3 & 2.06 & 0.58 \\
\hline AE19 & 15 & 62 & 22.3 & 2.14 & 0.60 \\
\hline AE20 & 15 & 66 & 22.7 & 2.24 & 0.63 \\
\hline AE21 & 15 & 71 & 23.4 & 2.33 & 0.65 \\
\hline AE22 & 20 & 43 & 19.5 & 1.70 & 0.49 \\
\hline AE23 & 20 & 47 & 20.2 & 1.79 & 0.51 \\
\hline AE24 & 20 & 53 & 20.7 & 1.97 & 0.56 \\
\hline AE25 & 20 & 57 & 21.3 & 2.06 & 0.58 \\
\hline AE26 & 20 & 62 & 22.3 & 2.14 & 0.60 \\
\hline AE27 & 20 & 66 & 22.7 & 2.24 & 0.63 \\
\hline AE28 & 20 & 71 & 23.4 & 2.33 & 0.65 \\
\hline & & & & & \\
\hline
\end{tabular}

The measured parameters are given in Table 2 where $d_{s}$ is equilibrium scour depth, $W_{s}$ is the scour hole width, $\mathrm{L}_{\mathrm{s}}$ is the scour hole length and $\mathrm{V}$ is the scour hole volume.

The schematic sketch of the scour hole is given in Figure 2. 

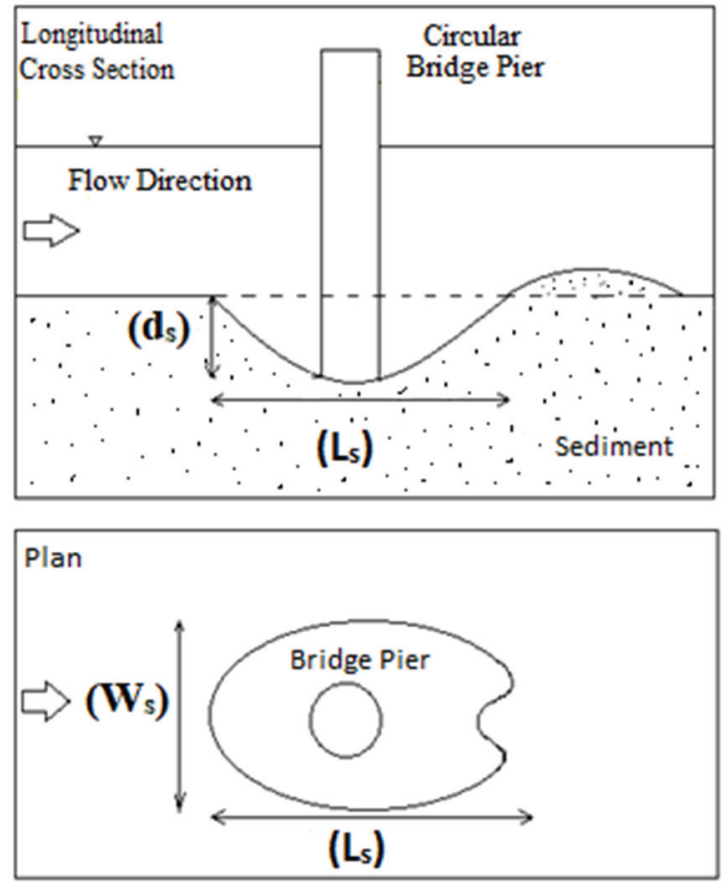

Fig. 2 - Schematic sketch of the scour hole [18]

After each experiment, the longitudinal and cross sections were measured by means of laser meter with a resolution up to $0.2 \mathrm{~mm}$. A grid was determined to measure the scour hole dimensions. Each grid cell has a dimension of $2 * 5 \mathrm{~cm}$. That means measurements were taken for every two centimeters along the flow direction and every five centimeters along the channel cross-section. The scour hole volume was calculated by means of measured data for each experiment.

The measured longitudinal and cross sections are given in Figure 3 and 4, respectively.

Table 2 - The results of the experiments

\begin{tabular}{|c|c|c|c|c|}
\hline $\begin{array}{c}\text { Experiment } \\
\text { No }\end{array}$ & $\begin{array}{c}\mathrm{d}_{\mathrm{s}} \\
(\mathrm{cm})\end{array}$ & $\begin{array}{c}\mathrm{W}_{\mathrm{s}} \\
(\mathrm{cm})\end{array}$ & $\begin{array}{c}\mathrm{L}_{\mathrm{s}} \\
(\mathrm{cm})\end{array}$ & $\begin{array}{c}\mathrm{V} \\
\left(\mathrm{cm}^{3}\right)\end{array}$ \\
\hline AE1 & 3 & 29.8 & 21 & 173.56 \\
\hline AE2 & 5.5 & 29.6 & 26 & 664.22 \\
\hline AE3 & 8 & 29.6 & 32 & 1553.31 \\
\hline AE4 & 9 & 33.6 & 34 & 2674.39 \\
\hline AE5 & 10 & 39.4 & 38 & 5571.06 \\
\hline
\end{tabular}


Table 2 - The results of the experiments (continue)

\begin{tabular}{|c|c|c|c|c|}
\hline $\begin{array}{c}\text { Experiment } \\
\text { No }\end{array}$ & $\begin{array}{c}\mathrm{d}_{\mathrm{s}} \\
(\mathrm{cm})\end{array}$ & $\begin{array}{c}\mathrm{W}_{\mathrm{s}} \\
(\mathrm{cm})\end{array}$ & $\begin{array}{c}\mathrm{L}_{\mathrm{s}} \\
(\mathrm{cm})\end{array}$ & $\begin{array}{c}\forall \\
\left(\mathrm{cm}^{3}\right)\end{array}$ \\
\hline AE6 & 10.2 & 39.8 & 38 & 5365.91 \\
\hline AE7 & 11.2 & 40 & 46 & 7073.01 \\
\hline AE8 & 4.7 & 31 & 28 & 590.04 \\
\hline AE9 & 6.7 & 30 & 32 & 1344.90 \\
\hline AE10 & 10.4 & 47.8 & 42 & 3364.78 \\
\hline AE11 & 11.3 & 44.4 & 44 & 4651.27 \\
\hline AE12 & 12.8 & 50.8 & 50 & 7372.02 \\
\hline AE13 & 13.7 & 59.2 & 54 & 10138.80 \\
\hline AE14 & 14.6 & 53 & 60 & 15721.23 \\
\hline AE15 & 4.4 & 33.6 & 36 & 2404.00 \\
\hline AE16 & 6.8 & 44.2 & 42 & 2169.93 \\
\hline AE17 & 11.9 & 48.6 & 52 & 6905.75 \\
\hline AE18 & 13.3 & 56.6 & 58 & 7775.07 \\
\hline AE19 & 15.9 & 62 & 68 & 15579.21 \\
\hline AE20 & 16.6 & 62.2 & 70 & 22329.12 \\
\hline AE21 & 18.4 & 69.4 & 84 & 26596.91 \\
\hline AE22 & 7.2 & 51.6 & 44 & 2551.91 \\
\hline AE23 & 8.7 & 54.6 & 52 & 3894.75 \\
\hline AE24 & 10.2 & 61 & 58 & 9951.24 \\
\hline AE25 & 13.8 & 69 & 70 & 15444.34 \\
\hline AE26 & 16.1 & 71.4 & 76 & 28393.91 \\
\hline AE27 & 19.2 & 79 & 88 & 31081.73 \\
\hline AE28 & 20.6 & 79.2 & 96 & 42944.73 \\
\hline
\end{tabular}

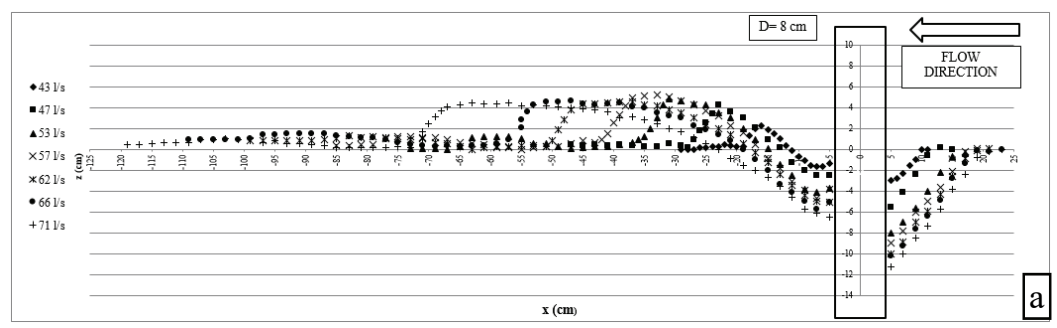

Fig 3 - The longitudinal sections measured after each experiment a) $D=8 \mathrm{~cm}, b) D=11 \mathrm{~cm}$, c) $D=15 \mathrm{~cm}$, d) $D=20 \mathrm{~cm}$. 
Investigation of Local Scour Hole Dimensions around Circular Bridge Piers under ...
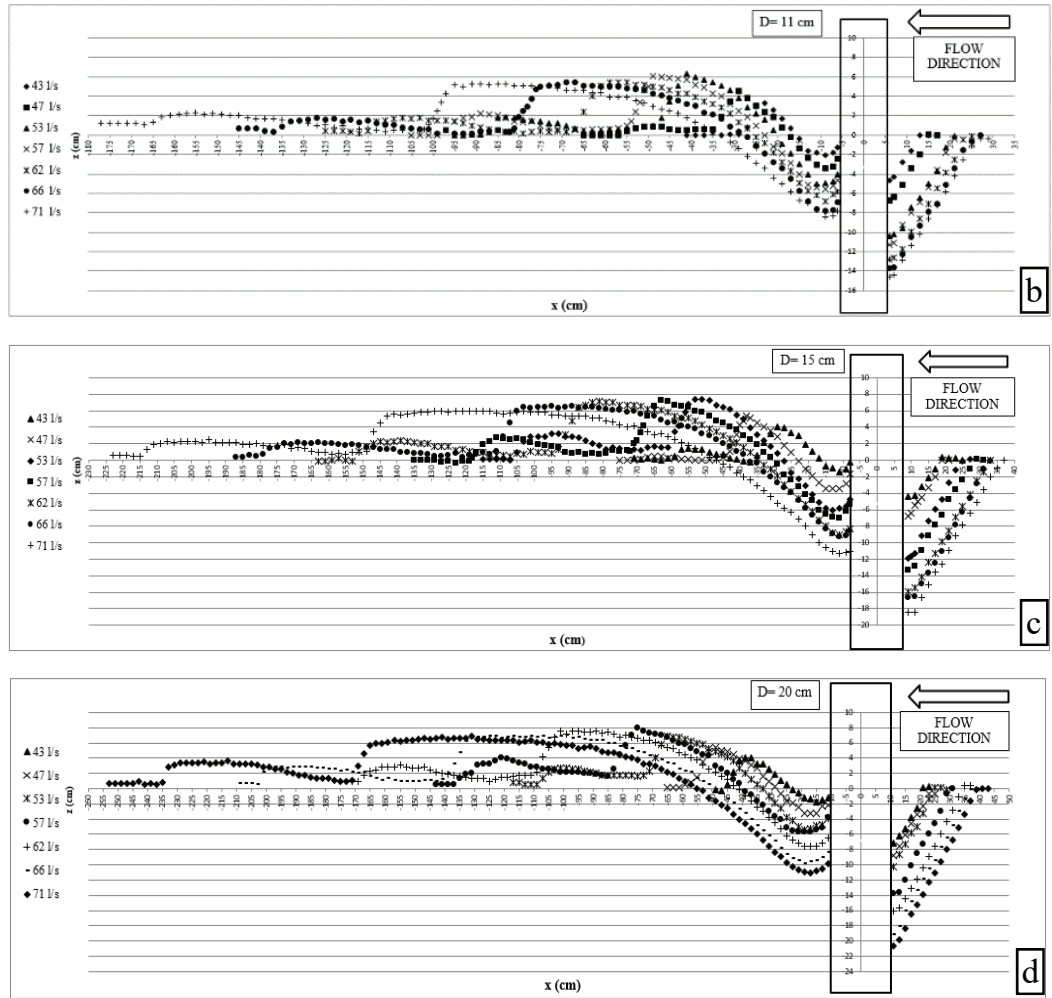

Fig 3 - The longitudinal sections measured after each experiment a) $D=8 \mathrm{~cm}, b) D=11 \mathrm{~cm}$, c) $D=15 \mathrm{~cm}, d) D=20 \mathrm{~cm}$. (continue)

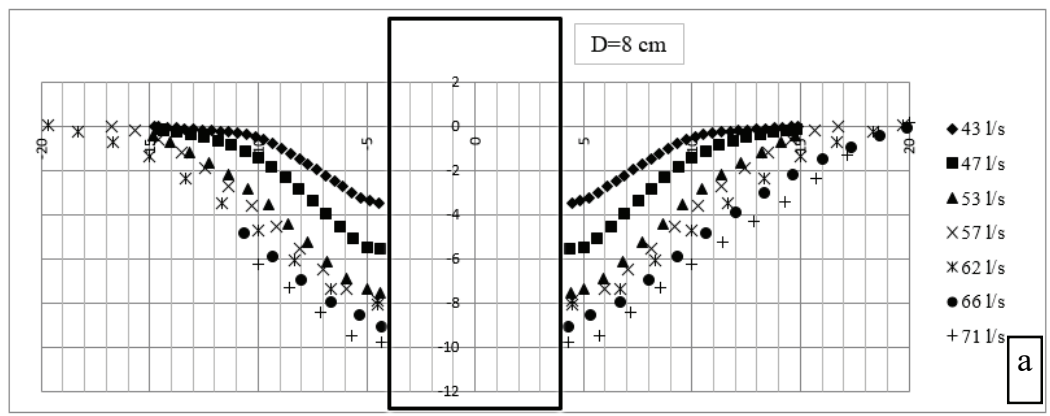

Fig 4 - The cross sections measured after each experiment a) $D=8 \mathrm{~cm}, b) D=11 \mathrm{~cm}$, c) $D=15 \mathrm{~cm}, d) D=20 \mathrm{~cm}$. 

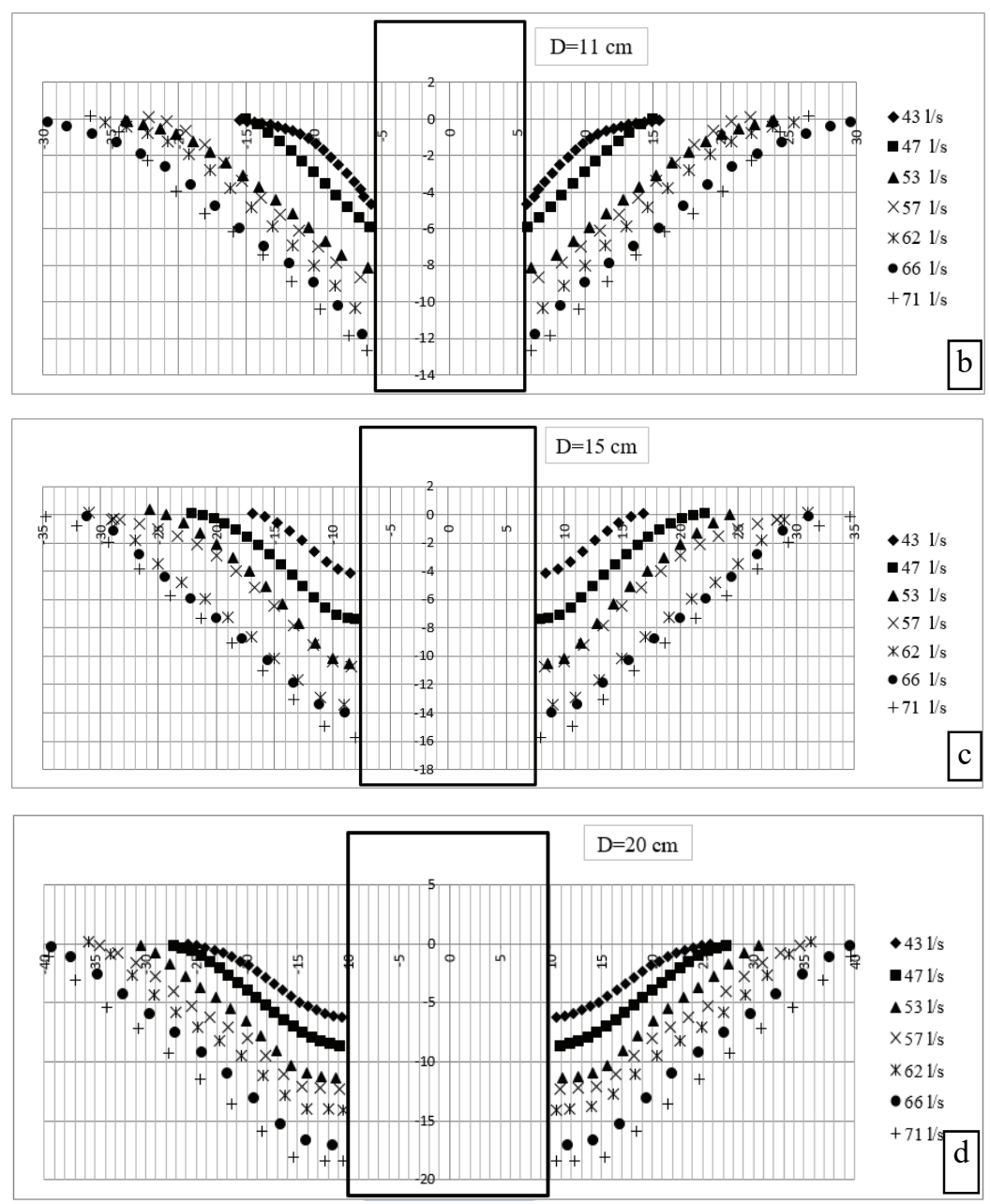

Fig 4 - The cross sections measured after each experiment a) $D=8 \mathrm{~cm}, b) D=11 \mathrm{~cm}$, c) $D=15 \mathrm{~cm}, d) D=20 \mathrm{~cm}$. (continue)

As seen from the graphs, the width and the length of the scour hole increase with the flow rate as expected. Accordingly, the volume of the scour hole increase with the flow rate. The equilibrium scour depth values increase depending on flow rate and diameter of the bridge pier. The maximum scour depth and scour hole volume were observed in the case of the largest flow rate $(Q=71 \mathrm{l} / \mathrm{s})$ and pier diameter $(\mathrm{D}=20 \mathrm{~cm})$.

28 additional experimental findings obtained by previous studies were taken into account to propose a more comprehensive and general equations. The features and the results of the additional experiments are given in Table 3 and Table 4, respectively. Only four scour hole volume data can be obtained from literature. 
Investigation of Local Scour Hole Dimensions around Circular Bridge Piers under ...

Table 3 - The features of the experiments obtained by previous studies ((A1-A16) D'Alessandro [20]; (B1-B4) Das et al.. [19]; (C1-C5) Hodi [21]; (D1-D3) Khan et al. [22])

\begin{tabular}{|c|c|c|c|c|c|c|}
\hline $\begin{array}{c}\text { Experiment } \\
\text { No }\end{array}$ & $\begin{array}{c}\mathrm{D} \\
(\mathrm{cm})\end{array}$ & $\begin{array}{c}\mathrm{y} \\
(\mathrm{cm})\end{array}$ & $\begin{array}{c}\mathrm{d}_{50} \\
(\mathrm{~mm})\end{array}$ & $\mathrm{F}_{\mathrm{d}}$ & $\begin{array}{c}\mathrm{V} \\
(\mathrm{m} / \mathrm{s})\end{array}$ & $\mathrm{V} / \mathrm{V}_{\mathrm{c}}$ \\
\hline A1 & 3 & 12 & 0.51 & 2.64 & 0.24 & 0.86 \\
\hline A 2 & 3 & 12 & 0.51 & 2.64 & 0.24 & 0.86 \\
\hline A3 & 10 & 12 & 0.51 & 2.64 & 0.24 & 0.86 \\
\hline A4 & 9 & 12 & 0.51 & 2.64 & 0.24 & 0.86 \\
\hline A5 & 8 & 12 & 0.51 & 2.64 & 0.24 & 0.86 \\
\hline A6 & 7 & 12 & 0.51 & 2.64 & 0.24 & 0.86 \\
\hline A7 & 9 & 12 & 0.51 & 2.64 & 0.24 & 0.86 \\
\hline A8 & 8 & 12 & 0.51 & 2.64 & 0.24 & 0.86 \\
\hline A9 & 7 & 12 & 0.51 & 2.64 & 0.24 & 0.86 \\
\hline A 10 & 10 & 12 & 0.51 & 2.64 & 0.24 & 0.86 \\
\hline A11 & 8 & 12 & 0.51 & 2.64 & 0.24 & 0.86 \\
\hline A 12 & 7 & 12 & 0.51 & 2.64 & 0.24 & 0.86 \\
\hline A13 & 9 & 12 & 0.51 & 2.64 & 0.24 & 0.86 \\
\hline A14 & 7 & 12 & 0.51 & 2.64 & 0.24 & 0.86 \\
\hline A 15 & 8 & 12 & 0.51 & 2.64 & 0.24 & 0.86 \\
\hline A16 & 7 & 12 & 0.51 & 2.64 & 0.24 & 0.86 \\
\hline B1 & 11 & 12.5 & 0.825 & 2.14 & 0.247 & 0.682 \\
\hline B2 & 15.5 & 12.5 & 0.825 & 2.14 & 0.247 & 0.682 \\
\hline B3 & 13 & 12.5 & 0.825 & 2.14 & 0.247 & 0.682 \\
\hline B4 & 11 & 12.5 & 0.825 & 2.14 & 0.247 & 0.682 \\
\hline $\mathrm{C} 1$ & 2 & 10 & 0.85 & 2.1 & 0.25 & 0.76 \\
\hline $\mathrm{C} 2$ & 2 & 10 & 0.85 & 2.1 & 0.25 & 0.76 \\
\hline $\mathrm{C} 3$ & 3 & 10 & 0.85 & 2.1 & 0.25 & 0.76 \\
\hline $\mathrm{C} 4$ & 3 & 10 & 0.85 & 2.1 & 0.25 & 0.76 \\
\hline $\mathrm{C} 5$ & 4.5 & 10 & 0.85 & 2.1 & 0.25 & 0.76 \\
\hline D1 & 5 & 8.2 & 0.54 & 2.82 & 0.264 & 0.936 \\
\hline D2 & 4 & 8.2 & 0.54 & 2.82 & 0.264 & 0.936 \\
\hline D3 & 3 & 8.2 & 0.54 & 2.82 & 0.264 & 0.936 \\
\hline
\end{tabular}


Table 4 - The results of the experiments obtained by previous studies ((A1-A16) D'Alessandro [20]; (B1-B4) Das et al.. [19]; (C1-C5) Hodi [21]; (D1-D3) Khan et al. [22])

\begin{tabular}{|c|c|c|c|c|}
\hline $\begin{array}{c}\text { Experiment } \\
\text { No }\end{array}$ & $\begin{array}{c}\mathrm{L}_{\mathrm{s}} \\
(\mathrm{cm})\end{array}$ & $\begin{array}{c}\mathrm{d}_{\mathrm{s}} \\
(\mathrm{cm})\end{array}$ & $\begin{array}{l}\mathrm{W}_{\mathrm{s}} \\
(\mathrm{cm})\end{array}$ & $\begin{array}{c}V \\
\left(\mathrm{~cm}^{3}\right)\end{array}$ \\
\hline A1 & 20.25 & 5.05 & 21.6 & No data \\
\hline $\mathrm{A} 2$ & 23.25 & 5.44 & 27.8 & No data \\
\hline A3 & 50.4 & 12.27 & 56.4 & No data \\
\hline A4 & 42.67 & 10.83 & 49 & No data \\
\hline A5 & 42.08 & 10.55 & 47.8 & No data \\
\hline A6 & 32.15 & 5.68 & 31.6 & No data \\
\hline A7 & 43.56 & 10.95 & 50.4 & No data \\
\hline A8 & 41.29 & 10.04 & 46.8 & No data \\
\hline A9 & 37.75 & 8.81 & 43.2 & No data \\
\hline A 10 & 45.36 & 11.09 & 50.6 & No data \\
\hline A11 & 38.11 & 9.37 & 45.8 & No data \\
\hline A12 & 39.14 & 9.32 & 46.1 & No data \\
\hline A13 & 41.78 & 8.66 & 43.2 & No data \\
\hline A14 & 32.85 & 8.11 & 40.6 & No data \\
\hline A 15 & 40.49 & 9.94 & 47.6 & No data \\
\hline A16 & 38.45 & 9.42 & 45.2 & No data \\
\hline B1 & 46 & 9.2 & 53 & 5835 \\
\hline B2 & 58 & 11.2 & 60 & 9545 \\
\hline B3 & 48 & 9.6 & 49 & 6842 \\
\hline B4 & 42 & 8.2 & 48 & 4780 \\
\hline $\mathrm{C} 1$ & 10.43 & 2.47 & 10 & No data \\
\hline $\mathrm{C} 2$ & 9.13 & 1.93 & 7 & No data \\
\hline $\mathrm{C} 3$ & 18.26 & 4.43 & 18.5 & No data \\
\hline $\mathrm{C} 4$ & 13.04 & 2.67 & 12 & No data \\
\hline C5 & 21.3 & 5.5 & 22.75 & No data \\
\hline D1 & 22.5 & 7 & 22.5 & No data \\
\hline $\mathrm{D} 2$ & 19 & 5.9 & 19 & No data \\
\hline D3 & 17 & 4.8 & 17 & No data \\
\hline
\end{tabular}


New empirical relations to estimate scour hole length $\left(\mathrm{L}_{\mathrm{s}}\right)$, scour hole width $\left(\mathrm{W}_{\mathrm{s}}\right)$ and scour hole volume $(\forall)$ were investigated by using the experimental findings obtained by present study and previous studies. The proposed relations were obtained by using the least squares method which minimizes the sum of squared residuals. Eq 15, Eq 16 and Eq 17 are proposed by using the experimental data obtained from the present study and experimental findings obtained by D'Alessandro [20], Das et al. [19], Hodi [21] and Khan et al. [22].

$$
\begin{aligned}
& \frac{L_{s}}{D}=3.39\left(\frac{d_{s}}{D}\right)^{0.54} F_{d}^{0.32} \\
& \frac{W_{s}}{D}=2.1\left(\frac{d_{s}}{D}\right)^{0.33} F_{d}^{0.91} \\
& \frac{V}{D^{3}}=0.99\left(\frac{d_{s}}{D}\right)^{1.95} F_{d}^{1.96}
\end{aligned}
$$

The comparison between the experimental results including the previous studies and computed values by using Eq 15, Eq 16 and Eq 17 are given in Figures 5, 6 and 7, respectively. The proposed equations were evaluated in terms of determination coefficient $\left(R^{2}\right)$ and scatter index $(S I)$. The SI indicates normalized measure of errors and lower values of SI means better model performance. These parameters are defined as follows:

$\mathbf{R}^{2}=\left[\frac{\sum_{i=1}^{n}\left(\mathbf{d}_{s, \text { measured }}-\overline{\mathbf{d}_{s, \text { measured }}}\right)\left(\mathbf{d}_{\mathrm{s}, \text { computed }}-\overline{\mathbf{d}_{s, \text { computed }}}\right)}{\sqrt{\sum_{\mathrm{i}=1}^{\mathrm{n}}\left(\mathbf{d}_{\mathrm{s}, \text { measured }_{i}}-\overline{\mathbf{d}_{s, \text { measured }}}\right)^{2} \sum_{i=1}^{n}\left(\mathbf{d}_{s, \text { computed }_{i}}-\overline{\mathbf{d}_{s, \text { computed }}}\right)^{2}}}\right]^{2}$

$\operatorname{SI}(\%)=\frac{\sqrt{\frac{\sum_{i=1}^{n}\left(d_{s, \text { measured }_{i}}-d_{s, \text { computed }_{i}}\right)^{2}}{n}}}{\overline{d_{s, \text { measured }}}} \cdot 100$

where $\overline{\mathbf{d}_{s, \text { measured }}}$ and $\overline{\mathbf{d}_{\mathbf{s} \text {,computed }}}$ are the arithmetic mean of the measured and computed scour depth values, respectively.

As shown in Figures 5, 6 and 7 the predicted scour hole dimensions are in good agreement with those obtained from experiments. the determination coefficient values $\left(R^{2}\right)$ were calculated as $0.98,0.95$ and 0.97 for $L_{s}, W_{s}$ and $\forall$, respectively. That means a strong relationship exist between the calculated and measured scour hole dimensions. So, the proposed equations can predict reliable scour hole dimension values. In addition computed scatter index values $(S I)$ support this strong relationship.

Measured experimental results were also compared with those calculated by using equations given by Yanmaz and Altınbilek [4], Khwairakpam et al. [18] and Das et al. [19]. The results are given Figures 8, 9, 10, 11, 12, 13 and 14, respectively. 


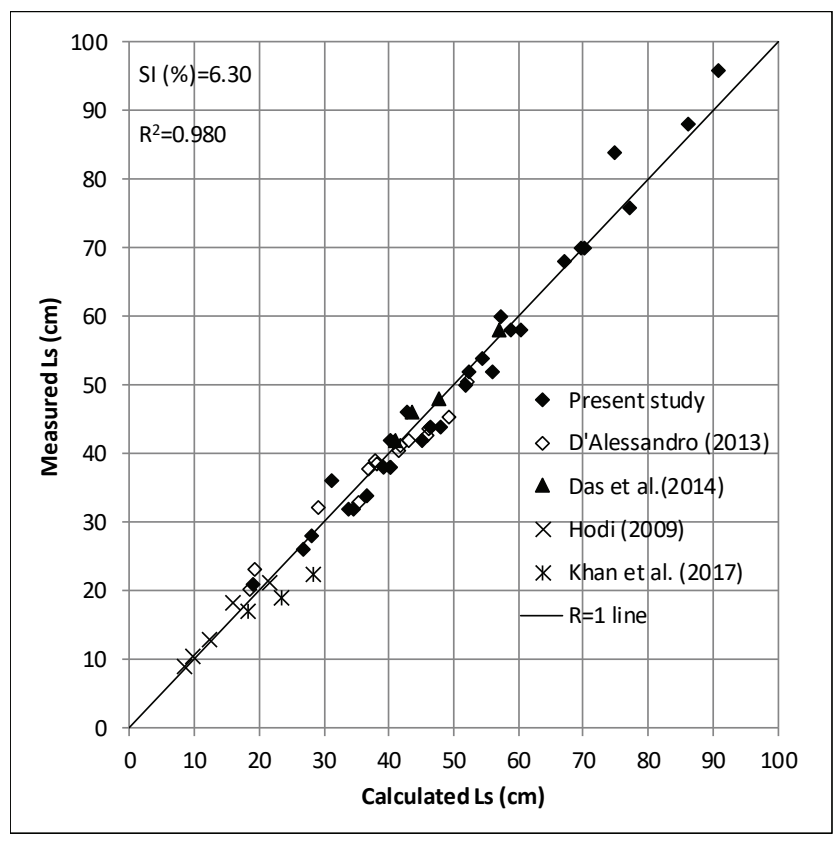

Fig. 5 - Comparison of measured and calculated $L_{s}$ values obtained by proposed equation

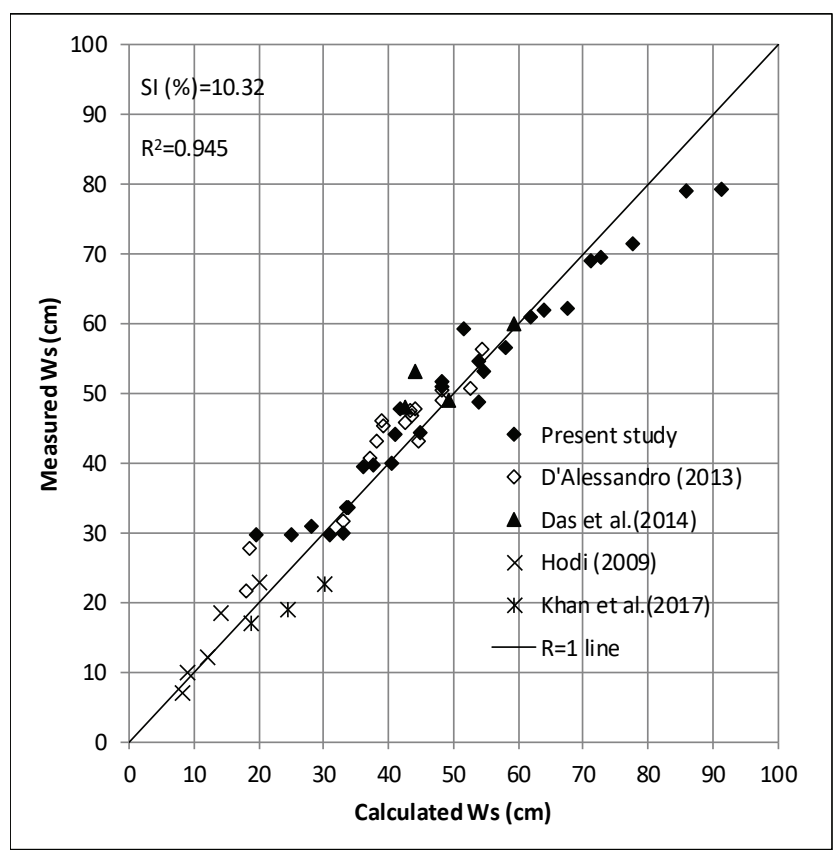

Fig. 6 - Comparison of measured and calculated $W_{s}$ values obtained by proposed equation 
Investigation of Local Scour Hole Dimensions around Circular Bridge Piers under ...

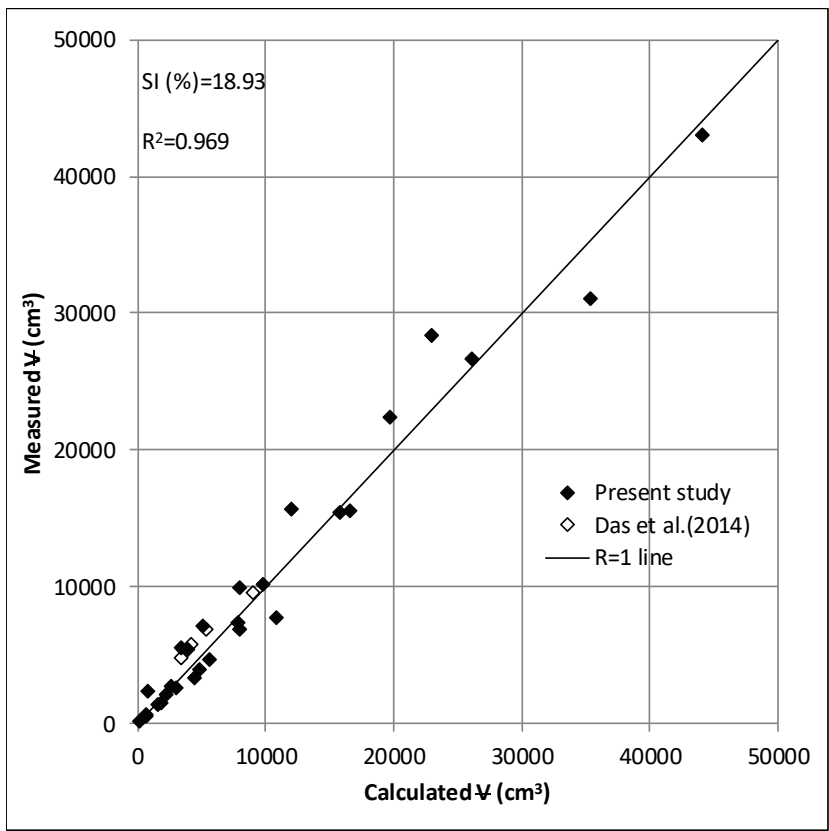

Fig. 7 - Comparison of measured and calculated $\forall$ values obtained by proposed equation

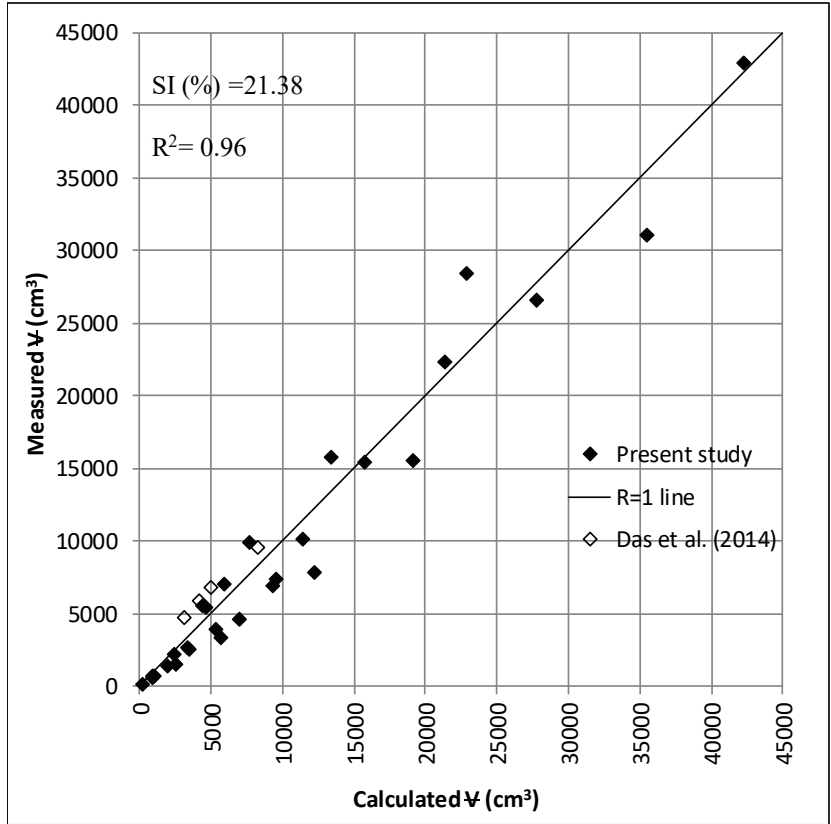

Fig. 8 - Comparison of measured and calculated $\forall$ values obtained by Yanmaz and Altınbilek (1991) equation 


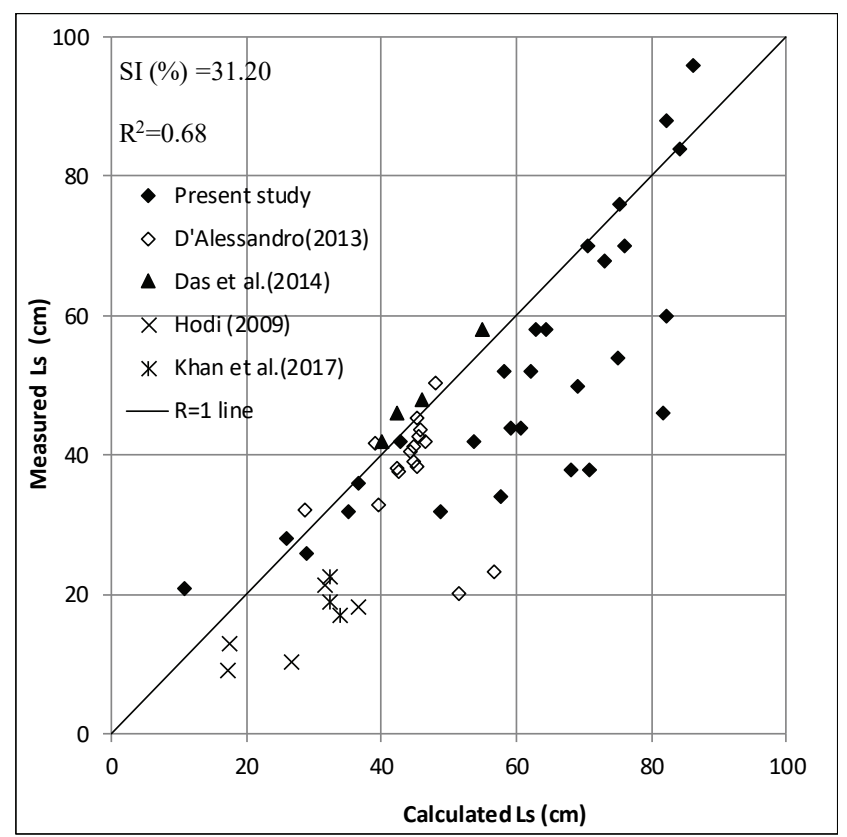

Fig. 9 - Comparison of measured and calculated $L_{s}$ values obtained by Khwairakpam et al. (2012) equation

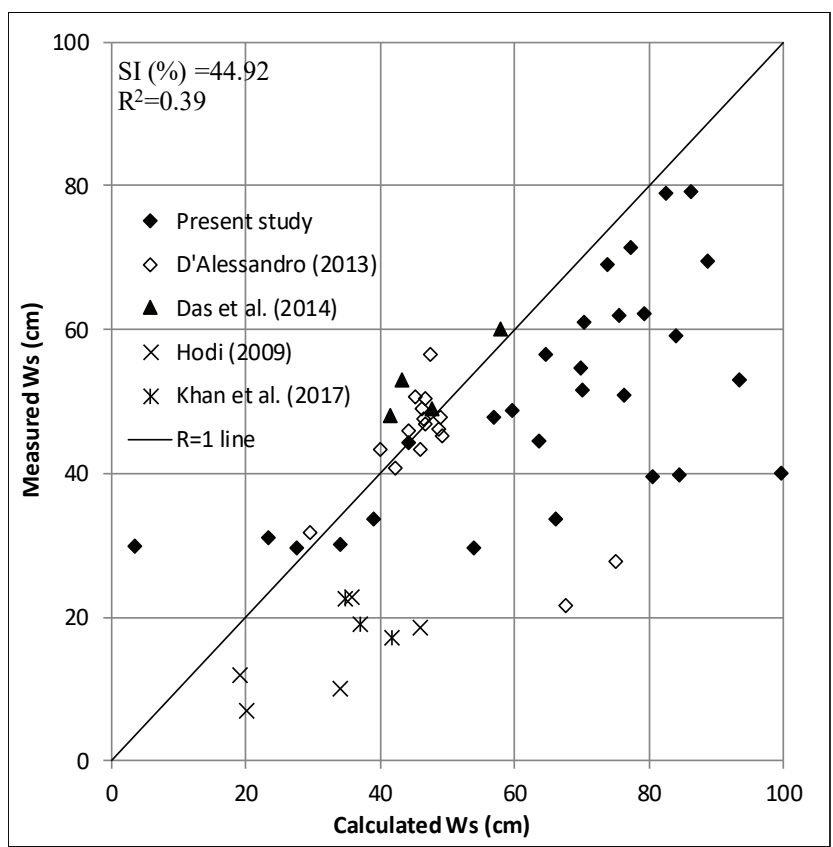

Fig. 10 - Comparison of measured and calculated $W_{s}$ values obtained by Khwairakpam et al. (2012) equation 
Investigation of Local Scour Hole Dimensions around Circular Bridge Piers under ...

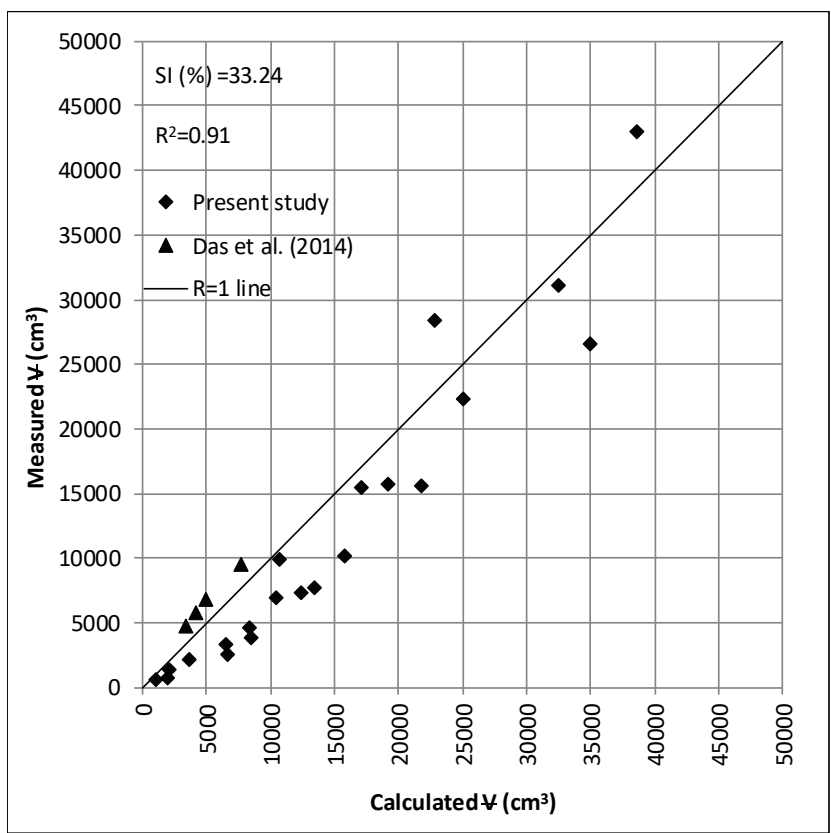

Fig. 11 - Comparison of measured and calculated $¥$ values obtained by Khwairakpam et al. (2012) equation

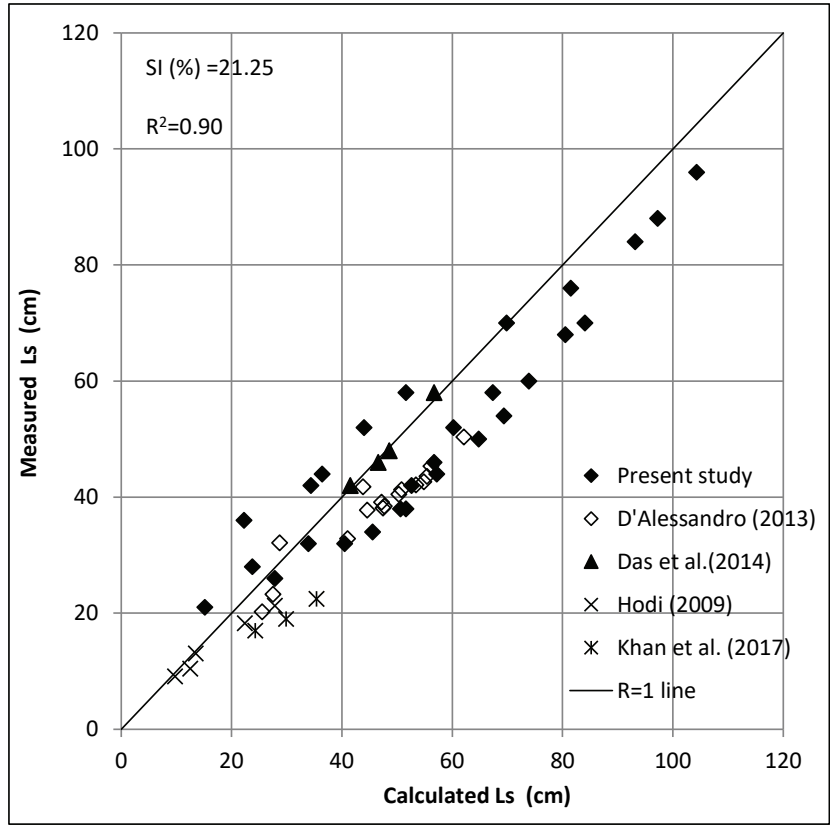

Fig. 12 - Comparison of measured and calculated $L_{s}$ values obtained by Das et al. (2014) equation 


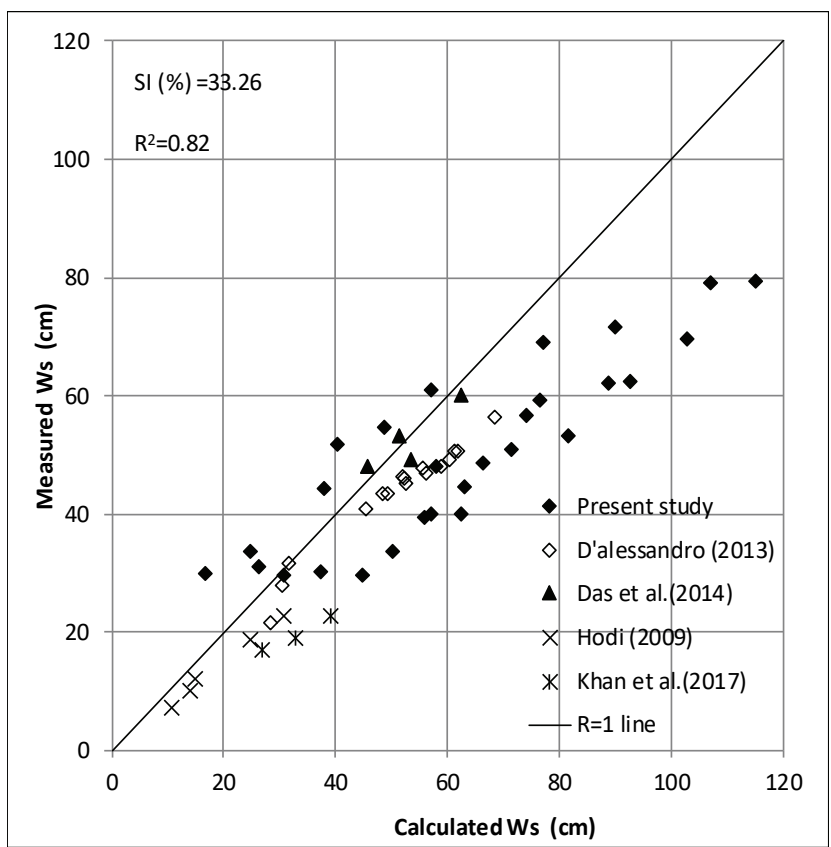

Fig. 13 - Comparison of measured and calculated $W_{s}$ values obtained by Das et al. (2014) equation

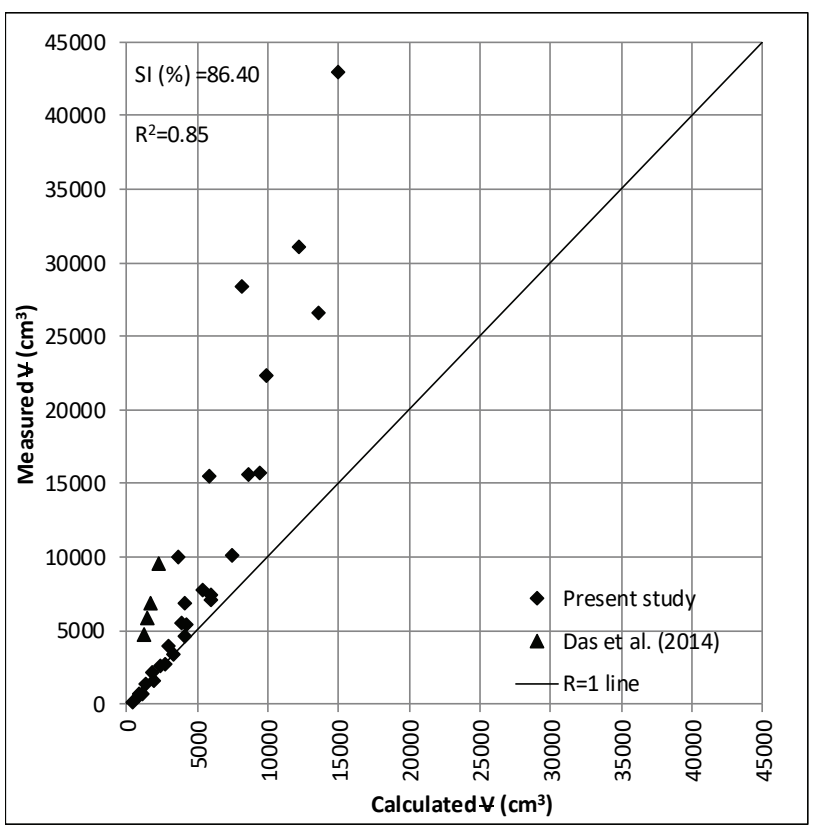

Fig. 14 - Comparison of measured and calculated $\forall$ values obtained by Das et al. (2014) equation 
According to the $\mathrm{R}^{2}$ and $\mathrm{SI}$ values given in the figures, the equation proposed by Yanmaz\&Altinbilek is in good agreement with experimental results obtained for volume values. The $\mathrm{R}^{2}$ values obtained for Khwairakpam et al. equation are smaller than those obtained from other equations. The main reason could be the large number of empirical coefficients used in the equations.

Scatter index and determination coefficient values corresponding to proposed and given by other researcher's equations are given in Table 5.

\section{Table 5 - Scatter index and determination coefficient values of various equations}

\begin{tabular}{|c|c|c|c|c|c|c|c|c|}
\hline & \multicolumn{2}{|c|}{$\begin{array}{c}\text { Yanmaz and } \\
\text { Altınbilek [4] }\end{array}$} & \multicolumn{2}{c|}{$\begin{array}{c}\text { Khwairakpam } \\
\text { at al. [18] }\end{array}$} & \multicolumn{2}{|c|}{ Das at al. [19] } & \multicolumn{2}{c|}{$\begin{array}{c}\text { Present } \\
\text { Equation }\end{array}$} \\
\hline & SI (\%) & $\mathrm{R}^{2}$ & SI (\%) & $\mathrm{R}^{2}$ & SI (\%) & $\mathrm{R}^{2}$ & SI (\%) & $\mathrm{R}^{2}$ \\
\hline $\mathrm{L}_{\mathrm{s}}$ & - & - & 31.20 & 0.68 & 21.25 & 0.90 & 6.30 & 0.98 \\
\hline $\mathrm{W}_{\mathrm{s}}$ & - & - & 44.92 & 0.39 & 33.26 & 0.82 & 10.32 & 0.95 \\
\hline$\forall$ & 21.28 & 0.96 & 33.24 & 0.91 & 86.40 & 0.85 & 18.93 & 0.97 \\
\hline
\end{tabular}

As shown in Table 5 the best agreement between measured and calculated parameters obtained by using present equations given in this study. The differences of the present equations are to involve the densimetric Froude particle number $\left(\mathrm{F}_{\mathrm{d}}\right)$. According to the results it is revealed that $F_{d}$ has an important role to estimate scour hole dimensions.

The statistical convenience of the proposed equations $\mathrm{Eq} \mathrm{15,} \mathrm{Eq} 16$ and $\mathrm{Eq} 17$ were also established by applying Fisher ( $\mathrm{f}$ ) test. If the calculated $\mathrm{f}$ value is greater than the critical $\mathrm{f}$ value, then the experimental data explain the regression equation with 0.01 confidence level. To compute the f value following equation is used.

$f=\frac{S S R / \vartheta_{1}}{S S E / \vartheta_{2}}$

where SSR is the sum of squared residuals, SSE is the sum of squares for error, $\vartheta_{1}$ is the number of the independent variables $(k)$, and $\vartheta_{2}=n-k-1$, ( $n$ is the number of the data). SSR and SSE can be calculated from the following equations:

$S S R=\sum_{i=1}^{n}\left(x_{i}^{\text {computed }}-\overline{x_{l}^{\text {measured }}}\right)^{2}$

$S S E=\sum_{i=1}^{n}\left(x_{i}^{\text {measured }}-x_{i}^{\text {computed }}\right)^{2}$

where $\overline{x_{l}^{\text {measured }}}$ are the arithmetic mean of the observed and computed values.

The critical value of $f$ depends on the number of the data and selected significance level. The critical values of $f$ for the 0.01 significance level are 5.18 for Eq 15 and Eq 16, and 5.42 for Eq 17. The f values were computed as 438,1231 and 447 for the equations of 15, 16 and 17 , 
respectively. Eventually, the significance of the proposed equations Eq 15, Eq 16 and Eq 17 are demonstrated.

\section{CONCLUSION}

In this study, scour hole dimensions around circular bridge piers were investigated under clear water scour conditions for various steady flow rates.

Four bridge piers with different diameters and seven different flow rates were used during the experimental tests. According to the experimental findings and experimental data available in the literature, three equations were proposed to estimate scour hole length $\left(\mathrm{L}_{\mathrm{s}}\right)$, scour hole width $\left(\mathrm{W}_{\mathrm{s}}\right)$ and scour hole volume $(\forall)$. The experimental results were also compared with those calculated using several empirical equations given by previous studies. The best fit between observed and calculated values was obtained by the proposed equation in this study. The statistical convenient of the equations were also investigated. The following conclusions were obtained according to the results of this study:

- The scour hole length, width and depth were increased with the pier diameter and mean flow velocity. The maximum scour hole occurred in the case of maximum rate of the flow and largest pier diameter used.

- The scour hole length, width and volume values were calculated by means of Equation 15, Equation 16 and Equation 17 and the results of the equations are in good agreement with experimental findings. The biggest difference of the proposed equation is that it contains the Froude particle number $\left(\mathrm{F}_{\mathrm{d}}\right)$ which has an important role to estimate the scour hole dimensions.

- To indicate the best fit equation scatter index (SI\%) values were computed for proposed and available equations given in the literature by using the observed and calculated scour hole length, width and volume values. According to the SI values it is revealed that proposed equations give the best fit between measured and calculated parameters and can be used to predict scour hole dimensions.

Since there is a lack of data about scour hole dimensions, the experimental findings are useful for the researchers investigating the scour hole dimensions and have contributed to the few experimental data in the literature.

\section{References}

[1] Laursen, E M. "Scour at bridge crossings", Bulletin No. 8, Iowa Highway Research Board, Ames, $\mathrm{IO}, 1958$, https://cedb.asce.org/CEDBsearch/record.jsp?dockey=0294630.

[2] Breusers, H.N.C., Nicollet, G., Shen, H.W., "Local scour around cylindrical piers", Journal of Hydraulic Resources, 15(3): 211-252, 1977, https://doi.org/10.1080/00221687709499645.

[3] Chiew, Y.M., Melville, B.W. "Local scour around bridge piers", Journal of Hydraulic Research, 25(1): 15-26, 1987, https://doi.org/10.1080/00221688709499285. 
[4] Yanmaz, M., Altinbilek, H.D. "Study of time dependent local scour around bridge piers", Journal of Hydraulic Engineering, 117(10): 1247-1268, 1991, https://doi.org/10.1061/(ASCE)0733-9429(1991)117:10(1247).

[5] Kandasamy J.K., Melville B.W. "Maximum local scour depth at bridge piers and abutments", Journal of Hydraulic Research, 36(2): 183-198, 1998, https://doi.org/10.1080/00221689809498632.

[6] Kothyari, U.C., Garde, R.J., Range Raju, K.G. "Temporal variation of scour around circular bridge piers", Journal of Hydraulic Engineering, 118(8): 1091-1106, 1992 , https://doi.org/10.1061/(ASCE)0733-9429(1992)118:8(1091).

[7] Melville, B.W. "Pier and abutment scour: Integrated approach", Journal of Hydraulic Engineering, 123(2): 125-136, 1997, https://doi.org/10.1061/(ASCE)07339429(1997)123:2(125).

[8] Melville, B.W., Chiew, Y.M. "Time scale for local scour at bridge piers", Journal of Hydraulic Engineering, 125(1): 59-65, 1999, https://doi.org/10.1061/(ASCE)07339429(1999)125:1(59).

[9] Richardson, E.V., Davis, S.R. "Evaluating scour at bridges", 5th ed. Hydraulic Engineering Circular No 18, Federal Highway Administration Publication No FHWANHI 01-001, Washington, DC,2001, https://www.fhwa.dot.gov/engineering/hydraulics/pubs/hif12003.pdf.

[10] Oliveto, G., Hager, W.H. "Temporal evolution of clear-water pier and abutment scour", Journal of Hydraulic Engineering, 128(9): 811-820, 2002, https://doi.org/10.1061/(ASCE)0733-9429(2002)128:9(811).

[11] Mia, F., Nago, H. "Design method of time dependent local scour at circular bridge pier", Journal of Hydraulic Engineering, 129(6): 420-427, 2003, https://doi.org/10.1061/(ASCE)0733-9429(2003)129:6(420).

[12] Chang, W.Y., Lai, J.S., Yen, C.L. "Evolution of scour depth at circular bridge piers", Journal of Hydraulic Engineering, 130(9): 905-913, 2004, https://doi.org/10.1061/(ASCE)0733-9429(2004)130:9(905).

[13] Kothyari, U.C., Hager, W.H. Oliveto, G. "Generalized approach for clear-water scour at bridge foundation elements", Journal of Hydraulic Engineering, 133(11): 12291240, 2007, https://doi.org/10.1061/(ASCE)0733-9429(2007)133:11(1229).

[14] Sheppard, D.M., Demir, H., Melville, B. "Scour at wide piers and long skewed piers", National Cooperative Highway Research Program Report 682, Transportation Research Board, Washington, DC, 2011, https://doi.org/10.17226/14426.

[15] Ozgenc Aksoy, A., Eski, O.Y. "Experimental investigation of local scour around circular bridge piers under steady state flow conditions", Journal of the South African Institution of Civil Engineering Vol 58 No 3, pp. 21-27, 2016, http://dx.doi.org/10.17159/2309-8775/2016/v58n3a3.

[16] Yılmaz, M., Yanmaz, A.M., Köken., M., "Experimental investigation of local scour around circular bridge piers under steady state flow conditions" IMO Teknik Dergi Vol 29 No 1, pp. 8167-8184, 2018, https://doi.org/10.18400/tekderg.345263. 
[17] Bor Turkmen, A., Guney, M.Ş., "Experimental Investigation of Scour Hole Characteristics for Different Shapes of Piers Caused by Flood Hydrograph Succeeding Steady Flow" IMO Teknik Dergi Vol 32 No 2, 2021, https://doi.org/10.18400/tekderg.595126.

[18] Khwairakpam, P., Ray, S. S., Das, S., Das, R., Mazumdar, A. "Scour hole characteristics around a vertical pier under clearwater scour conditions", ARPN Journal of Engineering and Applied Sciences, 7(6), 649-654, 2012, http://www.arpnjournals.com/jeas/research_papers/rp_2012/jeas_0612_704.pdf.

[19] Das, S., Das, R., Mazumdar, A. "Variations in clear water scour geometry at piers of different effective widths", Turkish Journal of Engineering \& Environmental Sciences, (38), 97-111, 2014, http://doi:10.3906/muh-1308-11.

[20] D'alessandro, C. M. "Effect of blockage on circular bridge pier local scour", Master of Thesis, Department of Civil and Environmental Engineering, Windsor University, Canada, 2013, http://citeseerx.ist.psu.edu/viewdoc/download?doi=10.1.1.918.5963\&rep=rep1\&type $=$ pdf.

[21] Hodi, B. S. "Effect of blockage and densimetric froude number on circular bridge pier local scour", Master of Thesis, Windsor University, Canada, 2009, https://core.ac.uk/download/pdf/72779078.pdf.

[22] Khan, M., Tufail, M., Fahad, M., Azmathullah, H.M., Aslam, M.S., Khan, F.A., Khan A. "Experimental Analysis Of Bridge Pier Scour Pattern", Journal of Engineering and $\begin{array}{lll}\text { Applied } & \text { Sciences, } & \text { Vol.36(1), } \\ \text { https:/journals uetjournals.com/index }\end{array}$ https://journals.uetjournals.com/index.php/JEAS/article/view/2.

[23] Melville, B. W, and Sutherland, A. J. "Design Method for Local Scour at Bridge Piers." Journal of Hydraulic Engineering, vol. 114, no. 10, pp. 12101226,1988https://ascelibrary.org/doi/abs/10.1061/(ASCE)07339429(1988)114:10(1210) 
